July 2008

\title{
Audience Measurement and Media Policy: Audience Economics, the Diversity Principle, and the Local People Meter
}

Philip M. Napoli

Fordham University

Follow this and additional works at: https://fordham.bepress.com/mcgannon_working_papers

Part of the Communication Commons

\section{Recommended Citation}

Napoli, Philip M., "Audience Measurement and Media Policy: Audience Economics, the Diversity Principle, and the Local People Meter" (2008). McGannon Center Working Paper Series. 4.

https://fordham.bepress.com/mcgannon_working_papers/4 
T H E

DONALD MCGANNON
COMMUNICATIONRESEARCHCENTER

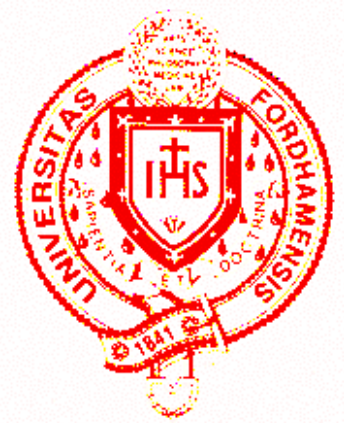

W O R I N G PAPER

\section{A UDIENCE MEASUREMENT AND MEDIA POLICY: A U D IENCE ECONOMICS, THE DIVERSITY PRINCIPLE, \& THE LOCAL PEOPLE METER}

Philip M. Napoli

Director

Donald Mc Gannon Communication Research Center A s sociate Professor, Schools of Business

Fordham University

Donald McGannon Communication Research Center Faculty Memorial $\mathrm{Hall}, 4^{\mathrm{th}} \mathrm{fl}$.

B r o n x, N Y 10458

718.817 .4195

ww w. ford ham.edu/mcgannon

mcgctr@fordham.edu

This research project was conducted with the assistance of a grant from the Fordham University Graduate School of Business Summer Research Assistance Grant Program.

The author wishes to thank McGannon Center Research Assistants Martin McNulty and Sheea Sybblis for their research assistance with this project. 
Audience Measurement and Media Policy:

Audience Economics, the Diversity Principle, and the Local People Meter

\begin{abstract}
This paper examines the policy implications surrounding Nielsen Media Research's introduction of the local people meter (LPM) system of television audience measurement. This paper explores the diversity policy considerations that have been raised in connection with the LPM introduction and examines whether the LPM represents a legitimate threat to source and content diversity, or whether the diversity principle has been largely co-opted in support of the economic and strategic considerations of certain industry stakeholders. This paper also addresses the broader question of whether the audience measurement industry should be subjected to more rigorous government oversight.
\end{abstract}


Audience Measurement and Media Policy:

Audience Economics, the Diversity Principle, and the Local People Meter

Introduction

The diversity principle long has been recognized as one of the central guiding principles in electronic media regulation and policymaking in the United States. ${ }^{1}$ Diversity as a media policy principle generally focuses on objectives such as maximizing the sources of information to which citizens/consumers have access, as well as maximizing the range of viewpoints and content options to which they have access. ${ }^{2}$ The principle of diversity has gained particular prominence in recent years in light of ongoing attention to the issue of media ownership regulation and the relationship between ownership concentration and the diversity of sources and content available to citizens/consumers. ${ }^{3}$ It is, however, important to recognize that diversity policy concerns extend beyond the realm of media ownership, addressing issues such employment, ${ }^{4}$ programming requirements, ${ }^{5}$ and the effects of marketplace constraints and incentives. ${ }^{6}$

Unfortunately, as with many of the established guiding principles in electronic media regulation and policy, the diversity principle frequently has served more as a rhetorical principle to justify policy outcomes than as an analytical tool for formulating and analyzing policy. ${ }^{7}$ In these instances, appeals to the diversity principle are made absent the underlying analysis of whether the policy outcomes being

\footnotetext{
${ }^{1}$ See Philip M. Napoli, Deconstructing the Diversity Principle, 49 J. of ComM. 7, 9-10 (1999).

${ }^{2}$ Id. at 12.

${ }^{3}$ See In re 2002 Biennial Regulatory Review, 18 F.C.C. Rcd. 13,620 (2003), aff'd, remanded to Prometheus Radio Project v. F.C.C., 373 F.3d 372 ( $3^{\text {rd }}$ Cir. 2004).

${ }^{4}$ The FCC's equal employment opportunity rules, and their presumed relationship to source and content diversity, provide a good example. See Philip M. Napoli, Foundations of CommunicATIONS Policy: PrinciPles AND PROCESS IN THE REGULATION OF ELECTRONIC MEDIA, 132-135 (2001). See also Lutheran Church-Missouri Synod v. F.C.C., 141 F.3d 344 (D.C. Cir. 1998) for an examination of the relationship between the EEO rules and diversity.

${ }^{5}$ Most diversity-motivated programming requirements, such as the Fairness Doctrine, the Prime-Time Access Rule, and the Financial Interest and Syndication Rules, have been eliminated over the past two decades. See Jim H. Snider, The Decline of Broadcasters' Public Interest Obligations: New America Foundation Spectrum Policy Program Policy Backgrounder, at <http://www.newamerica.net/Download/pdfs/Pub_File_1518_1.pdf >. ${ }^{6}$ For example, marketplace constraints affecting the availability of minority-interest programming. See Philip M. Napoli, Audience Valuation and Minority Media: An Analysis of the Determinants of the Value of Radio Audiences, 46 J. OF BROAdCASTING \& EleC. Media 169, 180-81 (2002); See generally Steven S. Wildman \& Theomary Karamanis, The Economics of Minority Programming, in INVESTING IN DIVERSITY: ADVANCING OPPORTUNITIES FOR MinORITIES AND MEDia 47 (Amy K. Garmer, ed.,1998). This issue is central to the activities of the FCC's Advisory Committee for Diversity in the Digital Age; see http://www.fcc.gov/DiversityFAC.

${ }^{7}$ See generally Napoli, supra note 4, at127-148.
} 
proposed indeed contribute to the preservation or enhancement of diversity. Because of the value that is, for the most part, universally placed on diversity in the media, the diversity principle can easily be exploited as a potent rhetorical tool in justifying or advocating particular policy outcomes.

The most recent high profile manifestation of the diversity principle has been in the realm of television audience measurement, where Nielsen Media Research’s efforts to launch the local people meter (LPM) measurement service have been met with strong industry resistance, as well as resistance from minority groups decrying the inadequacy of the local people meter in terms of measuring minority audiences. These stakeholders' central argument is that the undercounting of minority viewers characteristic of the LPM system will impact the availability of minority-targeted programming and, hence, the diversity of content available on television. ${ }^{8}$ Although the audience measurement industry generally is not subject to government regulation, the expressed diversity harms that have been prominent in the resistance to the LPM have caught the attention of policymakers, with congressional hearings taking place in Washington, DC, a number of stakeholders calling for government regulation of the television audience measurement industry, and, most recently, a congressional directive being given to the Federal Trade Commission to explore possible regulatory actions. ${ }^{9}$

Thus, due in large part to the centrality of the diversity principle, the realms of audience measurement and media policy have begun to intersect. This paper explores how and why the diversity principle has become enmeshed in this audience measurement controversy. In addition, this paper explores whether the LPM issue represents a situation in which genuine diversity harms are at risk. Should policymakers fear the impact of the local people meter on the diversity of content available on television, or is this a case of a public interest principle being used to mask industry self interest?

In addressing these issues, this paper examines the history of Nielsen Media Research's efforts to introduce the local people meter. This paper also examines the key stakeholders involved in this controversy, their main arguments, the evidentiary basis underlying these arguments, and what, if any,

\footnotetext{
${ }^{8}$ Anthony Bianco, How Nielsen Stood Up to Murdoch, Bus. WK., Sept. 2004, at 88.

${ }^{9}$ See infra p. 20 and note 83.
} 
policy interventions are appropriate. In conducting this analysis, this paper draws upon a variety of primary and secondary sources, including industry trade press reports, press releases, correspondence, and research reports of involved individuals and stakeholder groups, court decisions, and congressional reports and testimony. Ultimately, this paper is concerned with the question of whether the introduction of the local people meter indeed represents a threat to source and content diversity warranting a policy response and, if so, what the appropriate response should be. This paper also addresses the broader issue of whether the audience measurement industry should be subject to government regulation, and if so, on what grounds.

The first section of this paper reviews the intersection between audience measurement and media policy in order to provide context for the analysis being conducted here. The second section chronicles the introduction of the local people meter and the resistance to it that has existed since its inception. This section examines the main stakeholders involved in the LPM controversy as well as the primary arguments they have employed. The third section examines the methodological assessments that have been conducted up to this point on the accuracy of the local people meter and its ability to effectively represent minority television viewing. The concluding section assesses whether the local people meter represents a legitimate threat to diversity on television and what, if any, policy responses should be employed as a result. This concluding section also addresses the broader question of if and how the audience measurement industry should be regulated.

\section{Audience Measurement and Media Policy}

Despite the centrality of audience measurement to the operation of the electronic media, intersections between audience measurement and media policy are relatively infrequent. The Federal Communications Commission’s regulatory authority, which has, over time, expanded beyond broadcasting to include other electronic media such as cable and satellite (and, somewhat tangentially, the Internet), has never expanded to such a point as to include the organizations that measure these media's audiences. 
There have, however, been a number of instances in which communications policymakers have, at least indirectly, addressed audience measurement. For instance, the Cable Television Act of 1992 includes language that prevents cable companies from selling the audience behavior data that they are able to gather and aggregate via the set top boxes placed in subscribers' homes to third parties. ${ }^{10}$ These limitations are in place in order to protect the privacy of cable television viewers. ${ }^{11}$ There remain, however, questions regarding whether the Cable Act restrictions apply to DBS operators and other noncable-based providers of video programming. These are questions that policymakers may need to address directly in the near future. ${ }^{12}$

More recently, the Federal Communications Commission has examined the question of the appropriate definition of radio markets (for the purposes of ownership regulation), a definitional process that has relied upon the market definitions established by Arbitron, the nation's leading provider of radio audience data. $^{13}$ In 1996, the FCC switched from relying upon Arbitron’s market definitions to relying upon a "signal contour" method of defining markets (in which market definition was determined primarily by signal reach as opposed to by population and socio-economic data). The resulting differences in market definition facilitated concentration of ownership of radio stations in certain anomalous markets to a degree so beyond congressional and FCC intent that the FCC revisited its method of defining radio markets in its June, 2003 media ownership decision and returned (with some modifications) to the Arbitron-based market definition approach that it had abandoned in $1996 .{ }^{14}$

Clearly, while both of these examples illustrate some interaction between audience measurement and media policy, neither involves direct regulation of the established third-party providers of audience

${ }^{10}$ Cable Television Consumer Protection and Competition Act, Pub. L. No. 102-385, 106 Stat. 1460 (1992) (codified as amended at 47 U.S.C. §§ 521-609 (2000)).

${ }^{11} 47$ U.S.C. $\S \S 521-609$.

${ }^{12}$ Philip M. Napoli, Audience Economics: Media Institutions And the Audience MarketPlace (2003).

${ }^{13}$ David M. Hunsaker, Duopoly Wars: Analysis and Case Studies of the FCC's Radio Contour Overlap Rules. 2 COMmLAW CONSPECTUS 21, 25 (1994). The FCC similarly relies upon Nielsen Media Research's definition of television markets in its television-related policymaking and policy analysis. See generally Napoli, supra note 4, at 268-74.

${ }^{14}$ See Amy Jo Coffey, In Search of a New Radio Market Definition: “The Modified Metro.” The paper was presented at the annual meeting of the Association for Education in Journalism \& Mass Communication in Toronto, Canada (Aug. 2004). 
data. The nearest such occurrence took place in the late 1950s and early 1960s, as a result of a series of congressional investigations of the broadcast ratings industry. ${ }^{15}$ These investigations were spearheaded by Arkansas Representative Oren D. Harris (D), Chair of the House Committee on Interstate and Foreign Commerce. The Harris Commission (as the investigating body was commonly known) gathered 30 days of testimony and compiled a record of over 1700 pages, ultimately producing a final report in $1966{ }^{16}$

Although these investigations did not lead to direct government regulation of the audience measurement industry, they did lead to the establishment of an independent review organization (originally called the Broadcasting Rating Council - now known as the Media Rating Council) to assess and certify audience measurement systems. ${ }^{17}$ To the extent that the Harris Commission’s report addressed regulatory responsibility for the Federal Communications Commission, it was primarily within the context of monitoring broadcast licensee's false or deceptive use of ratings data, rather than in terms of the behavior of the actual measurement firms. ${ }^{18}$ The Federal Trade Commission also was identified by the Commission as needing to have responsibility for the truthful and accurate reporting and usage of ratings data. However, in the end the Commission's report concluded that industry self-regulation of the audience measurement industry was preferable to government regulation, ${ }^{19}$ a policy position that has remained in place to this day.

More recently, and perhaps most relevant to the subject at hand, in 1994 Illinois Representative Cardiss Collins (D), then-Chair of the House Energy and Commerce Committee’s Subcommittee on

\footnotetext{
${ }^{15}$ For a thorough overview of these investigations and their impact, see Karen S. Buzzard, CHAINS OF GoLD, MARKETING THE RATINGS AND RATING THE MARKETS (1990). As audience researcher Hugh M. Beville points out, these investigations came on the heels of a number of high profile congressional investigations of the media industry, including investigations of the infamous quiz show scandal and of payola in the radio industry; see Hugh M. Beville, Audience Ratings: Radio, Television, Cable (1988).

${ }^{16}$ Broadcast Ratings, Report of the Committee on Interstate and Foreign Commerce, Special Subcommittee on Investigations, U.S. Government Printing Office, Washington, DC, 1966.

${ }^{17}$ The Broadcast Rating Council was established in 1964 by the Research Committee of the National Association of Broadcasters under the chairmanship of Donald McGannon, then-president of Westinghouse Broadcasting, before the Harris Committee investigation had even concluded. See Beville, supra note 15, at 246-248.

${ }^{18}$ See generally Beville, supra note 15.

${ }^{19}$ Broadcast Ratings, supra note 16. According to the report, "It is highly doubtful that Government regulation of the operation of rating services, at this time, at least, is likely to be more effective than a well-administered program of industry self-regulation. Furthermore, there is not in existence at present any Federal agency which is discharging functions closely related to those performed under the program of self-regulation. The enactment of legislation providing for such regulation would not appear to be in the public interest at this time” (p. 19).
} 
Commerce, Consumer Protection and Competitiveness, organized a task force to examine Nielsen's effectiveness in measuring African-American television audiences. ${ }^{20}$ This task force, chaired by Collins, included representatives of Nielsen Media Research, the advertising industry, and African-American television producers. The task force originated from dissatisfaction among many stakeholders with how Nielsen was measuring African-American audiences, and the potential impact of poor measurement on the availability of African American-targeted programming. ${ }^{21}$ As was the case with the Harris Commission, the result of this inquiry was not direct government regulation, but internal industry changes in response to governmental pressure. As a result of the task force's activities, Nielsen initiated improvements in its methods of sampling and recruiting African-American viewers. ${ }^{22}$ Clearly, inherent in this issue, and in Nielsen's subsequent response, is the question of the extent to which the system of audience measurement employed at the time discouraged the production of a diversity of content options, originating from a diverse array of sources - a question that would become the focal point of the more recent iteration of this issue.

As these examples indicate, audience measurement intersects with a variety of important media policy issues (including privacy, ownership concentration, and diversity). However, these intersections have remained largely at the periphery of media policy, with the well-known "raised eyebrow" approach of governmental intervention ${ }^{23}$ often producing alterations in industry practice that have forestalled direct government regulation. Most important within the context of this study is that concerns regarding the relationship between audience measurement and diversity clearly have an established foothold in the media policy arena.

The Nielsen Local People Meter: Introduction, Industry Response, and Policy Implications

\footnotetext{
${ }^{20}$ Brooks Boliek, Nielsen Study Due This Week; Task Force, Looking at Ratings’ Impact on Blacks, May Ask for Changes, HollywOOD ReP., Oct. 18, 1994.

${ }^{21}$ Brooks Boliek, Blacks Rate Nielsen Poorly; Lawmaker Says System Has “Adverse” Impact on Advertisers, Programs, Hollywood ReP., June 16, 1994.

${ }^{22}$ Jenny Hontz, Nielsen to Fix How it Tracks Black Viewers, EleCtronic Media, Oct. 24, 1994, at 50.

${ }^{23}$ See generally Napoli, supra note 6. See also, Erwin G. Krasnow, Lawrence D. Longley, \& Herbert A. Terry, THE POLITICS OF BROADCAST REGULATION (3d ed. 1982).
} 
Nielsen's local people meters first were introduced in the United States in 1999, when the devices were installed for a test run in the Boston, Massachusetts television market. The local people meter system is an effort to replace the widely criticized audimeter/paper diary system that exists in large television markets. Smaller markets employ only paper diaries. Under the existing system employed in large markets, set tuning data obtained via the audimeter (a device capable of recording the channel being viewed, but incapable of recording audience demographics) are melded with demographic information obtained four to six times throughout the year via paper diaries. ${ }^{24}$

Local people meters provide programmers and advertisers with detailed, demographic-level television audience data 365 days a year (as opposed to four or six months out of the year under the current system), available immediately (as opposed to months later, after diaries are tabulated), and minus the substantial participant recall error that is known to plague the diary system. ${ }^{25}$ The local people meter system is likely to remain confined to larger markets, however, where there is sufficient revenue to support it, due to the system's substantial expense. ${ }^{26}$

At the time that the Boston market was selected as the first test market for the LPM, some concerns were expressed within television and advertising industry circles about the choice. As was noted at the time, Boston is unusually homogeneous from a demographic standpoint when compared to other large television markets in the United States. ${ }^{27}$ Indeed, this homogeneity of the Boston market likely was a key deciding factor for Nielsen when making its choice, as it simplified the process of recruiting and maintaining a representative sample. ${ }^{28}$ As a result, although the LPM encountered substantial industry resistance in Boston (primarily from broadcasters), the debate over the merits of the

\footnotetext{
${ }^{24}$ For an overview of the process of measuring television audiences, see Napoli, supra note 12 , at 31.

${ }^{25}$ See Adrienne Lotoski, The Nielsen Local People Meter Initiative: Implications for Boston and Future Local Markets (unpublished manuscript, WCVB-TV (2000), on file with author).

${ }^{26}$ Id. Price increases associated with the local people meter service are estimated at 15-20 percent for Nielsen subscribers; see Brooks Barnes, For Nielsen, Fixing Old Ratings System Causes New Static, WALL ST. J., Sept.16, 2004 , at A8.

27 See Lotoski, supra note 25.

${ }^{28}$ George Ivie, Statement Before the United States Senate, Committee on Commerce, Science, and Transportation, Subcommittee on Communications, “Implementation of Nielsen Local People Meter TV Rating System” (July 15, 2004), available at http://commerce.senate.gov/pdf/ivie071504.doc.
} 
new system never revolved around the issue of diversity and the effectiveness of the LPM in capturing minority audience television viewing behaviors. ${ }^{29}$

The nature of the rhetoric surrounding the LPM system changed dramatically as Nielsen moved forward with its rollout, with New York, Los Angeles, Chicago, and San Francisco targeted for LPM conversion in 2004. According to many accounts, problems for Nielsen began after a meeting between Nielsen President and CEO Susan Whiting, News Corp. deputy COO Lachlan Murdoch (who also serves as CEO of the Fox Station Group), and News Corp. President Peter Chernin in early March of 2004 to discuss test results from the New York LPM system. ${ }^{30}$ According to Whiting, at this meeting Murdoch threatened to discredit Nielsen if she did not delay the LPM roll-out, though News Corp. executives denied making any such threat, saying that they only asked for a delay of the roll-out until methodological questions about the system's ability to measure minority viewers could be addressed. ${ }^{31}$ Subsequently, on March $22^{\text {nd }}$, Murdoch released a statement condemning the preliminary LPM results for undercounting minorities. ${ }^{32}$ Soon thereafter, three members of Congress, including New York Senator Hillary Clinton (D) and Montana Senator Conrad Burns (R), sent letters to Whiting expressing similar concerns about the LPM system, as did Julian Bond, Chairman of the NAACP's National Board of Directors. ${ }^{33}$ These voices of opposition soon were joined by New York political leaders, including Adriano Espaillat, Chair of the New York State Black, Puerto Rican, and Hispanic Legislative Caucus, Peter Rivera, Chair of the New York State Puerto Rican/Hispanic Legislative Task Force, New York Assemblyman Jose Rivera, and Democratic state Senate leader David Paterson. ${ }^{34}$ These public statements opposing the local people

\footnotetext{
${ }^{29}$ As one trade press account noted, "[Nielsen] gained critical momentum when it installed the system in Boston over protests from the local broadcast stations, but there it did so without the politically charged debate over racial makeup of the sample.” For Nielsen, Fear and Loathing in LA, MEDIA LIFE MAG. (May 11, 2004), available at http://69.20.6.242/news2004/may04/may10/2_tues/news1tuesday.html.

${ }_{30}$ Raymond Hernandez \& Stuart. Elliott, The Odd Couple Vs. Nielsen, N.Y. Times, June 14, 2004, at C1.

${ }^{31} I d$.

${ }^{32}$ Raymond Hernandez \& Stuart Elliott, Planned Nielsen Changes Criticized, N.Y. TimEs, Mar. 31, 2004, at C3.

${ }^{33}$ Karen Bachman, If I Can Make it There..., BROADCASTING \& CABLE, Apr. 5, 2004, at 6; see also Raymond Hernandez \& Stuart Elliott, supra note 31. See Letter from NAACP National Board of Directors Chairman Julian Bond to Susan Whiting (July 12, 2004) (on file with author). The NAACP eventually adjusted its position and decided to support the local people meter; see infra at p. 27.

${ }^{34}$ Press Release, Don't Count Us Out Coalition, Leading New York State Lawmakers Committed to Stop Nielsen from Undercounting Minority and Young Adult Viewers, (Mar. 28, 2004), available at
} 
meter rollout were accompanied by the formation of an organization called the Don't Count Us Out Coalition, a collection of advocacy groups opposed to the LPM system, ${ }^{35}$ that, it was later revealed, received its primary financing from News Corp. ${ }^{36}$

It is in these early statements of opposition to the LPM that the diversity principle quickly appears. For instance, the statement of Assemblyman Rivera noted that, "We have worked too long and too hard to try to create a diversity of voices in the media to see it all vanish due to one company’s stubbornness.” ${ }^{37}$ Rivera went on to call for Federal Communications Commission and Federal Trade Commission involvement in the issue. The relationship between diversity of voices and the audience measurement system was spelled out explicitly as follows:

This systematic undercounting [of minority viewers] could lead to the cancellation of numerous programs geared toward African American and Latino viewers, as well as impacting negatively on Spanish-speaking programming, dealing a serious blow to efforts to encourage diversity in the industry as a whole. ... Nielsen's decision to use LPMs in New York effective April $8^{\text {th }}$ directly threatens minority-oriented television programming, employment opportunities for minority producers, directors, actors, writers, and related businesses including advertising and television production. $^{38}$

Thus, from the outset the introduction of the local people meter in New York was framed by those opposed to the LPM as an issue of diversity policy requiring regulatory intervention. Moreover, as the above statement suggests, it was not only diversity of programming that was threatened, but also diversity

http://www.dontcountusout.com/pr032804/; see also David A. Paterson, Airwave Alert, N.Y. PosT, Apr. 5, 2004, available at http://www.dontcountusout.com/nypost040504/.

${ }^{35}$ See Hernandez \& Elliott, supra note 31. See also http://www.dontcountusout.com/about (last visited Jan. 2, 2005.)

${ }^{36}$ In June, 2, 2004, over two months after the creation of the Coalition, News Corp. issued a press release stating that, "We proudly acknowledge our support of the 'Don't Count Us Out' Coalition and their efforts on behalf of viewers and concerned citizens around the country." See Press Release, News Corp., Statement Regarding "Don't Count Us Out" Coalition, (June 20, 2004), available at http://www.newscorp.com/news/news 210.html. Further details about the organizational structure and financing of the Don't Count Us Out Coalition have proven elusive. See Marisa Hoheb, So What's the Don't Count Us Out Coalition Anyhow? Media LifE MAG. (June 17, 2004), available at http://69.20.6.242/news2004/june04/june14/4_thurs/news1thursday.html.

${ }^{37}$ See Statement Regarding "Don’t Count Us Out” Coalition, supra note 36, at 1.

${ }^{38} I d$. at 2. 
of sources (as represented by minority producers, directors, writers, etc.). Alex Nogales, president of the National Hispanic Media Coalition (a key opponent of the LPM rollout) went so far as to proclaim the LPM issue "an issue of civil rights for the entire entertainment industry.”39

A common theme among the many voices of protest was that Nielsen delay the April $8^{\text {th }}, 2004$ rollout of the local people meter in New York until explanations could be offered as to why the LPM system showed audiences for some minority-targeted programs to be significantly lower than they appeared under the paper diary system. ${ }^{40}$ On April $6^{\text {th }}$, Nielsen responded to these requests by announcing a delay of the launch of the New York LPM system until June $3^{\text {rd }}$ as well as the creation of a task force (with the help of New York Representative Charles Rangel (D)) to assess the LPM system and answer the questions about minority audience representation that had been raised. ${ }^{41}$ In responding to Nielsen's announcement, the Don't Count Us Out Coalition asked that the company engage in a variety of activities to improve the LPM system, including conducting independent verification and assessment of the LPM technology; engaging in a fully transparent decision-making process; ensuring that all community voices be represented on the Task Force; and addressing all methodological concerns before launching the service. ${ }^{42}$

It soon became clear, however, that the Don’t Count Us Out Coalition's ability to influence Nielsen extended not only from the political leaders supporting the Coalition's position, but also from an aggressive direct mail campaign encouraging viewers in New York not to cooperate with the ratings

\footnotetext{
${ }^{39}$ Quoted in Cynthia Littleton, People Meter Pulls in Protesters, Hollywood REP., May 11, 2004.

${ }^{40}$ Steve McClellan, Attack Mode, BroadCASTing \& CABLE, Apr. 5, 2004, at 40.

${ }^{41}$ Press Release, Nielsen Media Research, Congressman Charles B. Rangel and Nielsen Media Research Announce that Nielsen will Reschedule Launch of Local People Meters in New York City to June 3, (Apr. 6, 2004), available at http://www.nielsenmedia.com/newsrelease/2004/NY-LPM_postponed-4-04.htm. See also Karen Bachman, Cease Fire Declared, BROADCASTing \& CABLE, Apr.12, 2004, at 6. Task force appointees included Bob Barocci, President/CEO of the Advertising Research Foundation, Rev. James L Deemus III, Executive Director of the NAACP Chicago, and actor George Takei, best known as Mr. Sulu in the Star Trek television and movie series. The task force was chaired by former Illinois congresswoman Cardiss Collins, who had overseen a congressional investigation into Nielsen's measurement of minorities in 1996. See Press Release, Nielsen Media Research, Nielsen Appoints Prominent Community and Industry Leaders to Independent Task Force on TV Measurement (June 8, 2004), available at http://www.everyonecounts.tv/news/0608 taskforce.htm. See also Press Release, Nielsen Media Research, Four New Members Appointed to Task Force Studying Nielsen TV Ratings, (July 6, 2004), available at http://www.nielsenmedia.com/newsreleases/2004/TaskForce_NewMembers.htm.

${ }^{42}$ Press Release, Don't Count Us Out Coalition, Statement from Don't Count Us Out Coalition, (Apr. 6, 2004), available at http://www.dontcountusout.com/pr040604/.
} 
service, which, according to Nielsen, negatively impacted its ability to recruit minority households. ${ }^{43}$

This direct mail campaign led to statements from organizations such as the National Association of

Broadcasters and the Media Rating Council condemning such efforts to disrupt the audience measurement process. $^{44}$

The Don't Count Us Out Coalition also emphasized the results of a February, 2004 study conducted by the market research firm Rincon \& Associates (and funded by ABC and CBS) that detailed a variety of methodological flaws in Nielsen's system of measuring Latino audiences in four television markets (Los Angeles, Miami, New York, and San Antonio). ${ }^{45}$ Among this study’s many critical conclusions were that Latino audiences for English-language television programs may be severely underestimated by the Nielsen system; that the above average percentage of renters among Latino households may impact Nielsen's ability to sample Latinos effectively; and that foreign-born Latinos have significantly different viewing patterns than native-born Latinos - differences that are not captured effectively due to inadequacies in the Nielsen sample. ${ }^{46}$ Nielsen responded to this study with a rebuttal document citing methodological flaws in the Rincon \& Associates study, ${ }^{47}$ as well as by commissioning the Tomas Rivera Policy Institute, a Latino policy research organization based at the University of Southern California, to review the findings of the Rincon \& Associates study. ${ }^{48}$

\footnotetext{
${ }^{43}$ Steve McClellan, Delay Tactics, BroAdCASting \& CABle, 9 (Apr. 12, 2004).

${ }^{44}$ Press Release, National Association of Broadcasters, NAB Research Committees Issue Joint Statement Related to Publicity About Ratings Services, (Apr. 9, 2004), available at http://www.nab.org/Newsroom/PressRel/Releases/Research_Committees_on_Ratings041204.htm; Press Release, Media Rating Council, Inc., New York People Meter Statement, (May 28, 2004), available at http://www.mrc.htsp.com/images/0_51pr5-28_mrc\%20ny\%20lpm\%20statement.pdf

${ }^{45}$ Rincon \& Associates, LATINO TELEVISION STUDY (Feb.1, 2004), available at http://www.lulac.org/Issues/Media/LatinoTVstudy.pdf\#search='Rincon\%20\&\%20Associates,\%20LATINO\%20TEL EVISION\%20STUDY'

${ }^{46} I d$.

${ }^{47}$ Nielsen Media Research, Rincon LPM Rebuttal (2004), available at http:www/nielsenmedia.com/Rinconrebuttal.htm.

${ }^{48}$ Press Release, Nielsen Media Research, Nielsen Retains Tomas Rivera Policy Institute to Review Study of Latino Television Viewers (May 10, 2004), available at http://www.nielsenmedia.com/newsreleases/2004/TomasRiveraPolicy_Eng-5-04.htm.
} 
In June of 2004, the Tomas Rivera Policy Institute released the results of its review. ${ }^{49}$ The review argued that there were numerous methodological flaws in the Rincon study (such as a reliance on listed phone numbers in the sampling frame for its telephone survey), concluding that the Rincon study "does not provide conclusive evidence that warrants its criticism against the Nielsen methodology."50 However, the Institute's review also concluded that there were potentially significant problems in Nielsen’s methodology (such as following the U.S. census methodology of excluding ethnically mixed households from its sampling frame of Latino households) that could produce a sample "that might be skewed in favor of Spanish dominant Latino households." ${ }^{51}$

One important point of the Tomas Rivera Policy Institute’s study, and one that is largely agreed upon by nearly all of the stakeholders party to this controversy, is that the people meter technology itself is far superior to the audimeter/paper diary method of gathering data, and that any flaws in the LPM system primarily are a function of sample selection, not of the measurement technology. ${ }^{52}$ Rincon \& Associates subsequently defended its methodology and conclusions in a follow-up white paper that drew parallels between the local people meter and the ongoing problems associated with developing and testing new voting machines. ${ }^{53}$

A much bigger blow to Nielsen's LPM initiative than the Rincon study came in the form of the announcement of the decision by the Media Rating Council on May 28 ${ }^{\text {th }}, 2004$ to withhold accreditation of the New York LPM service "until such time as Nielsen addresses certain matters of non-compliance

\footnotetext{
${ }^{49}$ Tomas Rivera Policy Institute, A Policy Review Paper Assessing the Nielsen and Rincon Study on Latino Television Viewing (June 2004), available at http://www.nielsenmedia.com/newsreleases/2004/TRPIReportLatinoTVviewing_FINAL.pdf.

${ }^{50}$ Id. at 4.

${ }^{51}$ Id. at 7.

${ }^{52}$ Id. at 20. See also Media Rating Council, Inc, supra note 44, at 1: "The Television Committee is fully supportive of people-meter measurement technologies, which are considered superior to the current meter-diary approach.”; Bob Barocci, Statement Before the United States Senate, Committee on Commerce, Science, and Transportation, Subcommittee on Communications, "Implementation of Nielsen Local People Meter TV Rating System" (July 15, 2004), available at http://commerce.senate.gov/hearings/testimony.cfm?id=1269\&wit_id=3656; Tom Arnost, Statement Before the United States Senate, Committee on Commerce, Science, and Transportation, Subcommittee on Communications, "Implementation of Nielsen Local People Meter TV Rating System" (July 15, 2004), available at http://commerce.senate.gov/hearings/testimony.cfm?id=1269\&wit_id=3653.

${ }^{53}$ Edward T. Rincon, Measurement Bias: The Value of a Second Opinion, (June, 2004), available at http://www.nhmc.org/files/82bbe57ab397bf9d77c54b13cd272add-MeasurementBiasWhitePaper(Final).pdf
} 
with the MRC’s Minimum Standards for Media Rating Research cited in the audit and certain other performance issues of the New York LPM.”54 The results of this confidential audit were subsequently leaked to the Los Angeles Times, which reported a number of details of the audit's findings in a June $15^{\text {th }}$, 2004 story. ${ }^{55}$ Important details included the fact that the audit found that one in six viewers was improperly classified as black and one in nearly 14 viewers was improperly labeled Hispanic. The audit also found that "fault rates” (the rate at which the data being gathered were, for various reasons, excluded from the overall sample) were at least nine percentage points higher for African-American households than for white households. ${ }^{56}$ In a subsequent interim report, Nielsen reported making substantial progress in addressing these problems with the system. ${ }^{57}$

The Media Rating Council is a non-profit industry association established in 1964 to ensure that audience measurement services are valid, reliable, and effective. The Council's origins date back to the Harris Commission investigation in the 1960 s. $^{58}$ As a result of this investigation, Congress recommended the creation of the MRC as an alternative to direct governmental oversight. It is important to note that, while the MRC can withhold accreditation to individual audience measurement services, it has no authority to prevent any organization from offering such services minus the MRC accreditation. Thus, in this case, the MRC's rebuke of the New York LPM, while a substantial black eye to Nielsen, in no way prohibited Nielsen from moving forward with the transition if it so chose. Indeed, Nielsen decided to move forward with the June $3^{\text {rd }}$ launch of the LPM despite the MRC's decision. ${ }^{59}$

This decision mirrored Nielsen’s approach in Boston, where it launched the LPM service after failing to receive MRC accreditation (though accreditation ultimately was received six months after the

\footnotetext{
${ }^{54}$ See Press Release, Media Rating Council, Inc., supra note 44.

55 James Bates, Nielsen Meters Faulted in Audit, L.A. TIMES, June 15, 2004, at C1.

${ }^{56} \mathrm{Id}$.

${ }^{57}$ Nielsen Media Research, Nielsen and the Local People Meters (June 17, 2004). See also Susan Whiting, Playing the Race Card in TV Ratings, L.A. TIMES, June 25, 2004, at B-13.

${ }^{58}$ See supra, note 15.

${ }^{59}$ Nielsen: We're Doing New York Anyhow, MEDIA LIFE MAG., June 1, 2004, available at http://www.medialifemagazine.com/news2004/june04/june01/2_tues/news1tuesday.html. See also Press Release, Nielsen Media Research, Nielsen Media Research to Begin Offering Local People Meter Data to New York Market on June $3^{\text {rd }}$ (June 1, 2004), available at http://www.nielsenmedia.com/newsreleases/2004/LPMdata_NYmarket_604.htm.
} 
launch). ${ }^{60}$ Further following the strategy employed in Boston, Nielsen decided to make the data from both the old and the new measurement systems available simultaneously for the first three months of the New York LPM rollout, a decision that was heavily criticized by many stakeholders. ${ }^{61}$ As a representative of Spanish-language broadcaster Univision stated, “To put out two different kinds of currency is ludicrous. . . This is insufficient, it’s irrelevant, and it does a disservice to the industry."62 In the wake of Nielsen's decision, a number of other industry stakeholders, such as CBS, the Tribune Co., the American Association of Advertising Agencies, and the National Association of Broadcasters, publicly demanded that Nielsen stop the LPM rollout until the system had received MRC approval. ${ }^{63}$ The LPM Rollout Enters the Policy Arena

The rhetoric framing the Nielsen local people meter rollout as a diversity policy issue spilled into the media law and policy arena as a result of two developments in the summer of 2004. First, Univision filed a suit in Los Angeles Superior Court seeking an injunction against the July $8^{\text {th }}$ rollout of the Los Angeles LPM system. The suit accused Nielsen of unfair, unlawful, and deceptive business practices. ${ }^{64}$ A key part of Univision's argument was that “the LPM data will not only provide false guidance to advertisers and marketers, it will mask the market's diversity and jeopardize the future availability of news and entertainment programming dedicated to minority audiences.”, ${ }^{\text {,5 }}$ The suit also included a 24page statement from a former Nielsen executive (and current Univision executive) outlining the flaws in the LPM system, including claims that, in Los Angeles, Nielsen under-represents homes where Spanish is

\footnotetext{
${ }^{60} I d$.

${ }^{61}$ Stuart Elliott, Nielsen Offers Compromise, N.Y.TIMES, June 2, 2004, at C2; Diego Vasquez, Nielsen: We'll Do NYC Both Ways, MEDIA LIFE MAG., June 2, 2004, available at http://www.medialifemagazine.com/news2004/june04/june01/3_wed/news1wednesday.html.

${ }^{62}$ See Elliott, supra note 60 (quoting Ceril Shagrin, Senior VP for Corporate Research).

${ }^{63}$ CBS to Nielsen: Stop the LPM Rollout, MEDIA LIFE MAG., June 3, 2004, available at http://69.20.6.242/news2004/june04/june01/4 thurs/news1thursday.html; Tribune to Nielsen: Halt the LPM Rollout, MEDIA LifE MAG., June 4, 2004, available at http://www.medialifemagazine.com/news2004/june04/jun01/5_fri/news1friday.html; 4As and NAB Press Nielsen on Meter, MEDIA LIFE MAG., June 17, 2004, available at http://www.medialifemagazine.com/news2004/june04/jun14/4_thurs/news2thursday.html. ${ }^{64}$ Univision Sues Nielsen to Halt LA LPM, MEDIA LIFE MAG., June 10, 2004, available at http://69.20.6.242/news/june04/jun07/jun07/04_thurs/news2thursday.html.

${ }^{65}$ Press Release, Univision, Univision Files Lawsuit Against Nielsen Media Research to Stop Local People Meter Implementation in Los Angeles (June 10, 2004), available at http://corporate.univision.com/jsp/en/pr/Los_Angeles_10062004-2.jsp.
} 
the primary language by 37 percent and under-represents homes headed by 18-34-year-old Hispanics by 22 percent. $^{66}$

Univision’s effort failed, however, when Judge Stephen Czuleger of the Los Angeles Superior Court denied the request for the injunction, concluding that Univision had failed to show that the local people system violated the unfair competition law, or that it constituted unfair, unlawful, or fraudulent business practice.”67 Moreover, Judge Czuleger concluded that imposing such an injunction would represent a violation of Nielsen’s First Amendment rights. Czuleger went so far as to conclude that the ratings system might qualify as non-commercial speech (and therefore receive maximum First Amendment protection) because the intended audience for the data is not necessarily buyers of Nielsen's services. According to Czuleger, “Though advertising sellers and buyers rely on the ratings system, the ratings system itself does not propose a commercial transaction. Therefore, the speech can be afforded full First Amendment protection.”68 In the face of this decision, Univision elected to not move forward with its lawsuit. ${ }^{69}$

The second important policy development took place on July 15, 2004, when the Senate Commerce Committee held a hearing on the local people meter issue. ${ }^{70}$ The witness panel was composed of Tom Arnost, President of Univision, George Ivie, Executive Director and CEO of the Media Rating Council, Bob Barocci, President and CEO of the Advertising Research Foundation, Thomas Herwitz, President of Station Operations for Fox Television Stations, Inc., and Susan Whiting, President and CEO of Nielsen Media Research. While the bulk of the hearing was focused on the issue of Nielsen's methodology and the possible undercounting of minority viewers, ${ }^{71}$ the obvious subtext of the proceeding

\footnotetext{
${ }^{66}$ Steve McClellan, An Inside View, BROAdCASTING \& CABLE, June 21, 2004, at 3.

${ }^{67}$ Univision v. Nielsen, L.A. Super. Ct. (July 21, 2004). documentation pending from westlaw.

${ }^{68} \mathrm{Id}$. at 6. Immediately following the decision, Univision vowed to move forward with its lawsuit, but no additional action has been taken at this time. See Press Release, Univision, Univision Disappointed that its Request for a Preliminary Injunction of Local People Meter Implementation is Denied (July 1, 2004), available at http://www.corporate.univision.com/jsp/en/pr/Los_Angeles_01072004-1.jsp

${ }^{69}$ Press Release, Univision Dismisses Lawsuit Against Nielsen Concerning Use of Local People Meters (November 29, 2004), available at http://www.everyonecounts.tv/news/1129_univision.htm.

${ }^{70}$ Author attended hearing and documented proceedings (July 15, 2004). Notes available from author upon request.

${ }^{71}$ See, e.g., Tom Arnost, Statement Before the United States Senate, Committee on Commerce, Science, and Transportation, Subcommittee on Communications (July 15, 2004), supra note 52; Bob Barocci, Statement Before
} 
was whether Congress should step in and impose some sort of direct regulatory oversight over the television ratings business. Fox's Herwitz was the most vocal on this front, arguing that "this issue is now about much more than just whether the new ratings system is accurate. It is about the level of oversight necessary to protect consumers from the monopoly practices of Nielsen.,72 Herwitz went on to ask that Congress "establish an effective system of oversight to ensure that Nielsen is accountable to the public. Nielsen's current status as an unregulated monopoly that answers to no one has led to the damaging and unresponsive behavior we all have witnessed."73 Herwitz’s request was echoed by Univision’s Arnost, who noted that “The broadcast industry is regulated by Congress, yet Nielsen - the entity which most directly influences ownership limits and market share - is an unregulated foreignowned monopoly.... Univision has come to the reluctant conclusion that federal oversight is necessary and we respectfully ask you to seriously consider this option."74

Many of the members of Congress in attendance took the stance of being reluctant to regulate, but willing to consider it if they became dissatisfied with the industry's self-regulatory efforts. As California Congresswoman Barbara Lee (D) stated at one point, "I would hesitate to say that Nielsen is acting as a monopoly, but it is the only kid on the block. ... It is reasonable to ask whether this situation serves the public interest." ${ }^{\text {,75 }}$ The end result of this hearing (at least to this point), as is often the case in congressional-industry relations, was one of a vague threat of regulation should Nielsen not deal with the situation to Congress' satisfaction.

The diversity issue also factored prominently in the Senate hearing. Nielsen’s Whiting emphasized that although the LPM was indicating smaller minority audiences for many minority-targeted

the United States Senate, Committee on Commerce, Science, and Transportation, Subcommittee on Communications (July 15, 2004), supra note 52; Susan Whiting, Statement Before the United States Senate, Committee on Commerce, Science, and Transportation, Subcommittee on Communications, "Implementation of Nielsen Local People Meter TV Rating System” (July 15, 2004).

72 Tom Herwitz, Statement Before the United States Senate, Committee on Commerce, Science, and Transportation, Subcommittee on Communications, “Implementation of Nielsen Local People Meter TV Rating System” (July 15, 2004), available at http://commerce.senate.gov/pdf/herwitz071504.pdf

${ }^{73}$ Id.

${ }^{74}$ See Arnost, supra note 52.

75 See supra note 70. Lee is quoted from notes taken during attendance at congressional hearing (July 15, 2004) (on file with author). 
broadcast programs, minority audiences for many cable programs had increased dramatically (thereby potentially increasing cable networks’ ability/incentive to produce minority-targeted programming), and that the overall portrait of minority television viewing indicated by the new data was that "people of color watch a much wider array of programs than was previously indicated by the diary system." ${ }^{\text {76 }}$ This pattern, she concluded, "presents a compelling case for the television industry to focus more attention on African-American and Latino issues in a great many more shows." ${ }^{\text {,7 }}$ Ultimately, according to Whiting, the LPM would help enhance viewpoint and content diversity by "support[ing] specialized programming for people of color."78

\section{$\underline{\text { Aftermath }}$}

Subsequent to the Senate hearing, Nielsen moved forward with the Los Angeles, Chicago and San Francisco rollouts of the LPM system, receiving conditional accreditation for the Los Angeles service in August of 2004. ${ }^{79}$ Nielsen also announced a research alliance with the William C. Velasquez Institute, in which Latino social scientists would evaluate and make recommendations regarding all aspects of Nielsen’s television audience measurement systems. ${ }^{80}$ Nielsen’s Task Force also began hearing testimony from Nielsen clients and from members of the public interest community. ${ }^{81}$ In addition, despite the vocal resistance to the LPM, Nielsen signed multi-year agreements with three major television groups (Albritton Communications, Cox Television, and Granite Broadcasting) for LPM service in Atlanta, Detroit, San Francisco, and Washington. ${ }^{82}$

During this same time, the Don’t Count Us Out Coalition stepped up its attacks on Nielsen, with news releases highlighting the above average fault rate levels in minority households as well as instances

\footnotetext{
${ }^{76}$ See Whiting, supra note 71.

${ }^{77}$ Id.

${ }^{78} \mathrm{Id}$.

${ }^{79}$ Nielsen Gets “Conditional” Okay for LA Meters, Plans Update on Portable Meters, Press Release, Nielsen Media Research (Aug. 23, 2004), available at http://www.everyonecounts.tv/press/0823_meidapost.htm.

${ }^{80}$ Press Release, Nielsen Media Research, Nielsen and William C. Velasquez Institute Form Research Alliance to Improve Measurement of Latinos (Sept. 8, 2004), available at http://www.nielsenmedia.com/newsreleases/2004/WCVI-alliance_9-8-04.htm.

${ }^{81}$ Katy Bachman, Local People Meter Debate Continues, MediAWEEK., Sept.10, 2004.

${ }^{82}$ Press Release, Nielsen Media Research, Nielsen Signs Multi-Year Agreements with Three Station Groups for Local People Meter Service (Sept. 28, 2004), available at http://www.everyonecounts.tv/news/0928_station.htm.
} 
of viewership declines for cable networks such as BET (commonly identified as a beneficiary of the new, more accurate, LPM system). The Coalition also reiterated its call for FCC regulation of Nielsen. ${ }^{83}$ In terms of potential government regulation of Nielsen, Senator Conrad Burns (R) of Montana recently sent a letter to the Federal Trade Commission, asking that the agency explore whether it has the authority to "take action to ensure that the television ratings industry is run fairly and in the best interest of the public.” ${ }^{\prime 4}$ Burns specifically asked the FTC to determine whether Nielsen’s rollout of the LPM system without Media Rating Council approval violates the spirit and the letter of the Harris Commission report from $1966 .{ }^{85}$ Further, according to Burns, "If it is found that the present situation cannot be remedied within the existing framework, it is my intention to introduce legislation that would mandate specific actions to create an oversight regime to more effectively safeguard the public interest.” ${ }^{\text {}}$ Thus, it appears that more direct government oversight of the audience measurement industry may yet arise as a result of the local people meter controversy.

\section{Methodological Issues}

At the core of the debate over whether the local people meter represents a threat to viewpoint and content diversity in television is whether the LPM methodology under-represents minority television viewing. The difficulty in answering this question stems from the fact that there is no objective reality in regards to minority television viewing against which the results provided by the LPM system can be compared. As many audience behavior scholars have noted, audience ratings are a purely socially constructed phenomenon. ${ }^{87}$ To the extent that they always are drawn from a relatively small sample of the population of television viewers, they are at best a statistical abstraction used as a representation of an unknown reality. Thus, when the LPM results are compared to the results provided under the previous

\footnotetext{
${ }^{83}$ Press Release, Don't Count Us Out Coalition, Don't Count Us Out Coalition Calls on Rev. Jesse Jackson to Endorse Coalition's Proposal of FCC Regulation of Nielsen Monopoly, (Sept. 9, 2004), available at http://www.dontcountusout.com/pro090904.1/; Press Release, Don't Count Us Out Coalition, New Nielsen Data Shows BET Suffers Steep Ratings Declines When Measured Using Controversial New Local People Meter (LPM) System, (Sept. 16, 2004), available at http://www.dontcountusout.com/pr091604/.

${ }^{84}$ Letter from Conrad Burns to Deborah Platt Majoras, Chairman, Federal Trade Commission (Oct. 7, 2004), at 2, available at http://www.dontcountusout.com/resources/100704Burnsltr.pdf.

${ }^{85}$ Id.

${ }^{86} \mathrm{Id}$.

${ }^{87}$ Ien Ang, Desperately SEEKING THE AudienCE (1991); see also Napoli, supra note 12, at 39-48.
} 
meter/diary hybrid system in an effort to gauge the effectiveness of the LPM system in capturing minority viewing (as is often done by opponents of the LPM system), it is important to keep in mind that such comparisons really do not help answer the question of the accuracy of the LPM system.

The older meter/diary hybrid system provides its own socially constructed representation of the reality of television viewing. The system is widely regarded as having its own substantial flaws (including weaknesses in accurately measuring minority viewing) that have contributed to wide-spread skepticism - and widespread criticism of - its accuracy. ${ }^{88}$ Thus, if it is indeed the case that the meter/diary system exhibits larger minority audiences for certain programs or networks, these larger audiences may be the result of inaccuracies of the older system rather than inaccuracies of the new system. In that regard, it is worth emphasizing that even opponents of the LPM rollout do not praise the old system as superior from a measurement standpoint. Indeed, the people meter system is so widely acknowledged as superior to the meter/diary system that from a methodological assessment standpoint, drawing comparisons between the two systems is not a productive way of assessing the accuracy and reliability of the new system. Moreover, analyses that do emphasize such comparisons and use them as evidence of the inaccuracy of the LPM system can be easily dismissed as either seriously uninformed about the dynamics of the process of audience measurement, or as possibly attempting to cynically exploit concerns over diversity and the viability of minority-targeted programming - concerns that, within many sectors, likely are not accompanied by a deep understanding of the process of audience measurement. Ultimately, in assessing the accuracy of the LPM system, the key question that needs to be answered effectively is how well the system measures minority viewing relative to its ability to measure nonminority viewing.

That being said, the overall portrait of the television viewing audience does change dramatically as a result of the transition from audimeters/diaries to the local people meter. Overall, the trend is one of

\footnotetext{
$\overline{{ }^{88} \text { See Napoli, supra note 12, at 72-80. }}$
} 
increasing audiences for cable programming and decreasing audiences for broadcast programming. ${ }^{89}$ This pattern, not surprisingly, mirrors the pattern exhibited after the introduction of the national people meter system in the late 1980s. ${ }^{90}$ In terms of the size and distribution of minority audiences, the LPM system indicates overall declines in broadcast television viewing (relative to viewing levels exhibited under the audimeter/diary system) and increases in cable viewing; however, cable viewing is more widely dispersed across available content options than was indicated by the audimeter/diary system. ${ }^{91}$ Interestingly, the new system also suggests that a larger proportion of the audience for "minority-targeted" television programs is, in fact, white. ${ }^{92}$ Thus, for instance, diary-derived assumptions that audiences for certain African-American-targeted programs are roughly 75 percent African American are countered by LPM data, which indicate that the audiences are closer to one half to one third African- ${ }^{93}$

The end result of these patterns is that the audiences for certain minority-targeted broadcast network programs appear to decrease dramatically under the LPM system. For instance, AfricanAmerican targeted programs such as The Parkers, Girlfriends, and One on One experienced declines in viewers $18+$ of between 29 and 63 percent. ${ }^{94}$ However, it is important to recognize that these large audience declines are not isolated to minority-targeted programs. Non-minority-targeted programs such as Alias, Joan of Arcadia, and Jag also experienced significant declines (ranging from 30 to 55 percent). ${ }^{95}$

Nielsen has maintained that the lower ratings for many African-American-targeted broadcast television programs are not a function of measurement flaws within the LPM system, but rather reflect a more accurate portrait of minorities' television viewing behavior, in which a much greater diversity of

\footnotetext{
${ }^{89}$ Steve McClellan, Big Apple Count, BROADCASting \& CABLE, June 14, 2004, at10; Allison Romano, Measure for Measure, BROADCASTING \& CABLE, Oct.11, 2004, at 24.

${ }^{90}$ See William J. Adams, Changes in Ratings Patterns in Prime Time Before, During, and After the Introduction of the People Meter, 7 J. of Media Econ. 15 (1994); Beth E. Barnes \& Lynne M. Thomson, Power to the People(meter): Audience Measurement Technology and Media Specialization. In AudiENCEMAKING: How THE MEDIA CREATE THE AUDIENCE 75 (1994).

${ }^{91}$ Nielsen Media Research, Analysis of Local People Meter Usage in New York - March 2004, at 16 (May, 2004), available at

http://www.nielsenmedia.com/forclients/ResearchPaper_LPMAnalysis_NewYork.pdf\#search='Nielsen\%20Media\% 20Research,\%20Analysis\%20of\%20Local\%20People\%20Meter\%20Usage\%20in\%20New\%20York'

${ }^{92} \mathrm{Id}$.

${ }^{93} \mathrm{Id}$.

${ }^{94} \mathrm{Id}$. at 11 .

${ }^{95} \mathrm{Id}$. at 11 .
} 
programs is being viewed, and in which a much larger percentage of viewing time is spent watching cable programming. ${ }^{96}$ This correction comes about due to the fact that the participant recall (which tends to be biased towards broadcast programming) element that is fundamental to the diary system is eliminated under the people meter system. The overall result is one in which, according to Nielsen, "viewing to larger network programs tends to decline when shifting from meter/diary to people meter, regardless of the race or ethnicity of on-air talent."

This is a compelling argument, particularly in light of the fact that, in the wake of the replacement of the meter/diary system at the national level with people meters that took place in the U.S. in the late 1980s, there has been virtual consensus among industry stakeholders that the people meter is the far more accurate and reliable measurement system. ${ }^{98}$ Given that the shifts in ratings patterns indicated as a result of the introduction of the local people meter largely mirror the shifts in ratings patterns that took place after the introduction of the national people meter, it would seem, then, that the local people meter is performing similarly to the universally-embraced national people meter system.

Considering that the people meter technologies at the national and local level are virtually identical, it would stand to reason that any inadequacy that is unique to the LPM system would have to then be a function not of technology itself, but of other aspects of the data gathering, sampling, and recruitment processes employed by Nielsen at the local level. Assessments of these processes have been conducted internally by Nielsen, ${ }^{99}$ as well as externally via the Media Rating Council's audits ${ }^{100}$ and also are being conducted by the independent task force headed by former congresswoman Cardiss Collins. ${ }^{101}$

\footnotetext{
${ }^{96}$ Susan Whiting, Remarks Before the Black Consumer Research and Advertising Summit, Chicago, IL (June 30, 2004), available at http://www.everyonecounts.tv/news/0630_whitingremarks.htm.

${ }^{97}$ Nielsen Media Research, supra note 90, at 12.

${ }^{98}$ Napoli, supra note 12.

${ }^{99}$ See Nielsen Media Research, New York Local People Meter 2003: Super Q Audit Process (2004) (on file with author); Nielsen Media Research, Los Angeles Local People Meter 2003: Super Q Audit Process (2004) (on file with author). For a description of Nielsen's sampling and weighting processes, see Nielsen Media Research, Derivation of People Meter Household and Person Weights (2004) (on file with author).

${ }^{100}$ All Media Rating Council audits are confidential and thus are not publicly available. However, some of the details of the MRC's initial audit of the New York LPM system were reported by the Los Angeles Times, as a result of an unknown leak of the MRC's audit report. See supra note 55.

${ }^{101}$ See Press Release, Nielsen Media Research, supra note 41. The results of the Rangel Task Force's investigation are forthcoming.
} 
The two key methodological issues that have served as the focal point around discussions of the accuracy of the LPM system are: 1) household "fault rates;” and 2) accurate categorization of minorities in the sample. Fault rates refer to the rate at which the LPM equipment installed in participating households fails to provide complete or correct viewing information for one reason or another. According to Nielsen:

Faults occur when a home triggers the Nielsen processing system to automatically exclude the home's data for the given day. Faults can be triggered immediately upon identification of the condition, such as instances where the meter does not transmit data to the system or the meter otherwise does not provide tuning data. . . Faults are categorized either as "set faults" or "persons faults.” Set faults relate to the equipment in some way, such as an unplugged set or no data being received. Persons faults relate to the human element such as tuning without pressing the people meter button. ${ }^{102}$

If the equipment indicates a fault, then the household's viewing is not incorporated into Nielsen's audience estimates. Faulting occurs for a variety of reasons, including unplugged televisions, tuning to a station or network that has recently changed channel position, or tuning to a channel that is new to the subscriber's program line-up. New York LPM data for the summer of 2004 show an average fault rate of 14.6 percent. Households with five or more people have an average fault rate of 23.3 percent. Black households show a fault rate of 18.1 percent for this time period, while Hispanic households show a fault rate of 17.6 percent. ${ }^{103}$ Clearly, minority fault rates are somewhat above the average - a result that Nielsen attributes to the fact that "homes that watch more television are more likely to fault. It has nothing to do with race or ethnicity."104 According to Nielsen, the fact that minorities tend to watch more television than the average person, and the fact that minorities tend to live in larger than average

\footnotetext{
${ }^{102}$ Nielsen Media Research, New York Local People Meter, 2003: Super-Q Audit Process (2004) (on file with author).

${ }^{103}$ Susan D. Whiting, Response to Questions Presented by Members of the House Energy and Commerce Committee (July 12, 2004), available at http://www.everyonecounts.tv/news/documents/0712_houseresponse.pdf. ${ }^{104} I d$.
} 
households (in terms of number of people per household), contribute to the higher fault rates in minority households. $^{105}$

It also is worth noting that this fault rate discrepancy also is evident in Nielsen's national people meter sample, where a recent estimate placed fault rates nationally at 12 percent, but at 16.3 percent for Black households and 15.5 percent for Hispanic households. ${ }^{106}$ However, the growing opposition to the local people meter has not, for whatever reason, raised questions or concerns about the national people meter system. Thus, it remains the case that, at both the national and local levels, the people meter's ability to gather information from minority households has been somewhat weaker than its ability to gather information from non-minority households, though the magnitude of the difference - as represented by fault rates - is quite small. In recent correspondence with New York Senator Charles Schumer (D), Nielsen President and CEO Susan Whiting reported that the fault rates for minority households have been reduced to the 16-18 percent target level that is comparable to the national household average. ${ }^{107}$

Turning next to the issue of misclassification of participants in the measurement process, a primary reason Nielsen was denied certification for the New York LPM by the Media Rating Council was that the MRC's audit found that in two of the 30 homes audited for race, there were discrepancies in the race classification employed, and in two of the 27 homes audited for ethnicity, there were discrepancies in the ethnicity classification employed (i.e., the responses provided by these households to the auditor did not much those obtained by Nielsen. ${ }^{108}$

These results certainly indicate some shortcomings in the LPM system; however, it is important to recognize that, to the extent that Nielsen employs similar sample recruiting methods regardless of the specific technology ultimately used to measure audience behavior, it is difficult to say with any real

\footnotetext{
${ }^{105} \mathrm{Id}$.

106 Id. at 4.

${ }^{107}$ Letter from Susan D. Whiting to Senator Charles E. Schumer, at 4 (July 29, 2004), available at http://www.everyonecounts.tv/news/documents/Schumer.pdf.

${ }^{108}$ See Nielsen's Response to Issues Raised by the Media Rating Council, Media Advisory, Nielsen Media Research (June 17, 2004) (on file with author). This document also provides details describing how and why these misclassifications took place and the actions being taken to protect against such misclassifications.
} 
certainty that the problems identified by the MRC audit are in any way problems unique to the LPM system. To the extent that the misclassification problem is indicative of an issue potentially requiring some sort of regulatory intervention, it is perhaps best not thought of as an LPM problem, but as a broader audience measurement problem requiring attention across measurement systems and technologies. In the end, what we are likely to see is a pattern similar to that exhibited in Boston, wherein, after initial problems, the LPM system has been implemented in such a way as to withstand MRC scrutiny, as those charged with implementing the system have grown more experienced with the process. ${ }^{109}$

The shortcomings demonstrated in the LPM system at this point likely can be improved upon to a certain degree, but also are indicative of the persistent greater difficulty in measuring minority audiences that characterizes most forms of audience measurement. ${ }^{110}$ In assessing the quality of the LPM system, it also is important to examine the methodological improvements the system offers. For instance, relatively little attention has been paid by the various stakeholders in the LPM controversy to the fact that significant sample size increases are accompanying the LPM rollout in each market. ${ }^{111}$ While sample size and sample quality are not synonymous, larger sample sizes are crucial to effectively measuring what are increasingly fragmented television audiences. The rapid increase in the number of cable channels that a typical household receives is spreading audiences (minority and non-minority alike) ever thinner across available content options. ${ }^{112}$

In order to maintain reliable audience estimates in such an environment - particularly estimates that also contain accurate and reliable audience demographic breakdowns - it is vital that sample sizes increase. Nielsen is attempting to respond to this issue by increasing sample sizes such that, for example, the number of African-American households in the New York market under the LPM system will increase by one third over the meter/diary system. Similarly, the number of Latino households will

\footnotetext{
${ }^{109}$ Kevin Downey, Now Cable Really Counts, BroAdCASTING \& CABLE, June 7, 2004, at 38.

110 See Napoli, supra note 12, at 78-80.

${ }^{111}$ Press Release, Nielsen Media Research, Nielsen Making Largest-Ever Sample Size Increases Among AfricanAmericans \& Hispanic-Americans (Apr. 27, 2004), available at http://www.nielsenmedia.com/newsreleases/ 112 Napoli, supra note 12, at 176-7.
} 
increase by over fifty percent. ${ }^{113}$ These sample size increases will facilitate the more accurate and reliable measurement of increasingly fragmented television audiences, wherein the audiences for individual channels or networks tend to shrink as the number of channel options available to viewers increases. To the extent that minority audiences constitute a relatively small proportion of the television audience in most markets, the larger sample sizes employed by Nielsen Media Research should facilitate the more accurate and reliable measurement of such small audience groupings, regardless of how they distribute themselves across their available channels.

Further improvement in the gathering of audience behavior data should come from the fact that response rates for the people meter measurement system generally are higher than they are for diarybased measurement systems, across both minority and non-minority audiences. ${ }^{114}$ Moreover, the recall error that is an intrinsic element of any diary-based measurement system will be eliminated in local markets in which the LPM system is in use.

In sum, from a methodological standpoint, the greater accuracy likely to arise from the significantly more accurate measurement technology (audimeter/diary vs. people meter), and from the increased sample sizes, likely more than compensates for the inaccuracies associated with the slightly greater fault rates for minority households and for the instances of misclassification of minority households. This likely explains why industry response to the LPM roll-out is, with the exception of the broadcast industry, quite positive. ${ }^{115}$ For instance the African-American-targeted BET and TV One cable networks have strongly supported Nielsen in its LPM rollout, ${ }^{116}$ while Latino-targeted broadcast network Univision has opposed the LPM. To a certain degree, industry group stances on the LPM shake out along cable versus broadcast lines, with cable companies standing behind the LPM and broadcasters opposing

\footnotetext{
${ }^{113}$ See Nielsen Media Research, supra note 101. It is interesting to note that Nielsen also has encountered difficulties in accurately reflecting different income groups in its LPM samples. See, e.g., Nielsen Media Research, Los Angeles Local People Meter, 2003: Super-Q Audit Process (2004), though this problem has generated very little public discussion.

${ }^{114}$ See Napoli, supra note 12; see also Nielsen Media Research, supra note 90, at 6.

${ }^{115}$ See Downey, supra note 108; Joe Flint, News Corp.'s Nielsen Beef Looks Like a Red Herring, WALL ST. J. ONLINE, Apr. 13, 2004. "BET Reaches Out as Rivals Threaten; Channel Aims to Bolster Upfront Ad-Dollar Share Marketing Black Viewership” Wall ST. J. (Eastern ed), B3.

${ }^{116}$ Linda Moss, Black Nets Back LPMs, MulTiCHANNEL News, May 24, 2004, at 1.
} 
it. BET, not surprisingly, shows dramatic gains as a result of the transition to people meters, with ratings increases of an astounding 180 percent. ${ }^{117}$ This pattern corresponds with industry analyses that appear fairly unanimous in their conclusion that the local people meter will dramatically improve local cable's competitive position at the expense of local broadcast stations. ${ }^{118}$ As one industry analyst has noted, “Anytime you change a system of measurement, there will be winners and losers. And the losers are going to fight, scratch and claw to make sure they don’t lose too much.”119

What is more difficult to explain, however, is the lack of consensus in the minority media community in terms of its opposition to the local people meter. While some advocacy groups such as the National Hispanic Media Coalition have stood in opposition to the LPM, ${ }^{120}$ others, such as the Rainbow Push Coalition have supported it. ${ }^{121}$ Others, such as the NAACP, have actually reversed positions over time. After the NAACP initially spoke out against the LPM rollout, ${ }^{122}$ NAACP President Kweisi Mfume recently sent a letter to Susan Whiting of Nielsen stating that, “After much reflection and personal investigation, I have decided to support the Nielsen Media Research use of local people meters (LPM) as a vastly improved way of measuring television viewing. The LPM is clearly a more accurate and reliable way of tracking household viewing habits than any previous system.”123 It is possible that this lack of unity and consistency on the part of the minority community in relation to the local people meter issue is a function of different levels of understanding of the process of audience measurement - and perhaps a tendency to react immediately to some of the most glaringly negative aspects (from a minority programming standpoint) of the ratings differences between the LPM and audimeter/diary systems, regardless of whether they truly were an outgrowth of methodological shortcomings. It also is possible

${ }^{117} \mathrm{Id}$.

${ }^{118}$ See Napoli supra, note 12.

119 James Bates \& Meg James, Political Opposites Costar in a TV Ratings Drama; Murdoch's News Corp. and a Minority Coalition Seek to Delay New System for Counting Viewers, L.A. TiMES, June 3, 2004, at A1.

${ }^{120}$ See Littleton, supra note 39.

${ }^{121}$ See Reverend Jesse L. Jackson and Martin L. King, Jr., Open Letter Regarding Nielsen's People Meter Technology - A Step Forward for Inclusion and Fairness (Sept. 7, 2004), available at http://www.everyonecounts.tv/news/documents/Rainbow_Push_Letter.pdf.

${ }^{122}$ See Letter from NAACP National Board of Directors Chairman Julian Bond to Susan Whiting (July 12, 2004), supra note 33.

${ }^{123}$ See Letter from NAACP President and CEO Kweisi Mfume to Susan Whiting (October 18, 2004) at 1, available at http://www.everyonecounts.tv/news/documents/press\%20release\%20mfume.doc. 
that, to the extent that the transition to the LPM system harms the financial prospects of some of the most widely viewed and widely recognized minority targeted-programming (i.e., broadcast network programming), the transition could be perceived by some civil rights groups as detrimental to minority programming sources and minority targeted content even if the LPM improves the prospects for cable programming and is more sound than the audimeter/diary system from a methodological standpoint. Certainly, the history of audience measurement is well-populated with stakeholder groups advocating against methodological improvements that, from an objective standpoint, improve the measurement process, but from a self-interest standpoint, may undermine their competitive position. ${ }^{124}$

\section{Conclusion}

This paper has attempted to trace the intersection between audience measurement and media policy, as represented by the diversity concerns surrounding the introduction of Nielsen Media Research’s local people meter television audience measurement system. This study has illustrated how the process of television audience measurement can, in fact, raise legitimate diversity concerns via the potential underrepresentation of minority viewing and its consequent impact on advertiser and programmer decisionmaking. However, an examination of the methods associated with both the old and new systems of measuring television audiences, and of the methodological assessments of the LPM system, suggest that the local people meter may pose more of a threat to broadcast stations and their audience base than it does to viewpoint and content diversity on television. Thus, it appears that the diversity principle has been enmeshed in the local people meter issue primarily in an effort to camouflage broadcaster concerns about more accurate accounting of audience erosion to cable at the local level as a result of the switch to the LPM measurement system. By linking the introduction of the local people meter to the diversity issue, and by exploiting the concerns of the minority community (who likely are less versed in the intricacies of audience measurement than many of the other stakeholders involved in this process), the broadcast industry (led primarily by Fox and Univision) has managed to make the LPM introduction a media policy issue (i.e., a threat to diversity), when, in fact, it really is more of an issue of a shift in the competitive

\footnotetext{
${ }^{124}$ See Napoli, supra note 12.
} 
dynamics between local broadcast television and local cable. Diversity has become such a politically sensitive concept - particularly in the media policy arena in recent years - that it is particularly susceptible to being exploited in the policymaking process via the common strategy of wrapping industry self-interest in public interest rhetoric. And, as this example illustrates, this strategy can be employed to such a degree as to involve public interest-oriented advocates such as politicians and civil rights groups. $^{125}$

However, the likelihood that the LPM measurement system is not flawed or biased in such a way as to pose a legitimate threat to diversity - and may, in fact, promote diversity - does not mean that the linkage between audience measurement as a whole and diversity policy is illusory. Indeed, the potential for audience measurement to impact viewpoint and content diversity is real. ${ }^{126}$ Under-representation of minority viewing would reduce the economic incentives for programmers to air minority-appeal programming. Moreover, this relationship between audience measurement and diversity extends not only to the measurement of ethnic minorities, but also to the measurement of all forms of "niche" content that appeals to audience interests that are outside of the mainstream. Such niche programming is central to maximizing the diversity of our media system, and to the extent that there are any avoidable biases in the system of audience measurement that under-represent narrow-appeal programming relative to more mass appeal programming - and consequently discourage production and distribution of such programming, then legitimate diversity concerns are present. ${ }^{127}$

\footnotetext{
${ }^{125}$ As John Dunbar of the Center for Public Integrity illustrated within the context of the ongoing cable a la carte controversy (in which the diversity issue once again became the focal point), joint policy advocacy efforts between industry groups, civil rights groups, and politicians, when examined in detail (in terms of financial contributions, etc.), can be called into question in terms of whether legitimate public interest motivations are the guiding force, regardless of the nature of the rhetoric surrounding the advocacy. See John Dunbar, Anatomy of a Lobbying Blitz: Cable Industry Enlists Diverse Crowd in High Level Influence Campaign, Center for Public Integrity (2004), available at http://www.openairwaves.org/telecom/printer-friendly.aspx?aid=395.

${ }^{126}$ See Napoli, supra note 12, at 90, for a discussion of the "triple jeopardy" effect, which examines the factors that undermine the production of niche-targeted or minority-targeted programming, including the impact of audience measurement systems.

${ }^{127}$ See Wildman \& Karamanis, supra note 6. Audience measurement systems generally have greater difficulty in accurately and reliably reporting the audiences for programming with smaller audiences. While this programming may be minority-targeted programming, it also may be programming that appeals to narrow cultural or political viewpoints, or to other narrow demographic groupings; see Napoli, supra note 12, at 112-14.
} 
To the extent that communications policy in the U.S. has - and continues - to embrace diversity of viewpoints and content as central policy goals, the potential for audience measurement services to impact such diversity provides a compelling justification for government oversight. Moreover, there are particular characteristics of the existing industry self-regulatory system that undermine its ability to ensure that audience measurement is conducted in such a way as to assure measurement systems that do not, via inaccuracies, undermine viewpoint and content diversity. ${ }^{128}$ The particular problem with industry self-regulation extends from the substantial vested interests that can exist in favor of flawed audience measurement methods. To the extent, for example, that the broadcast industry traditionally has been by far the largest revenue source for Nielsen, they have been able to dictate, to a certain degree, how Nielsen goes about measuring television audiences. ${ }^{129}$ Indeed, only as cable has developed as an equal competitor to broadcast television has Nielsen begun to respond by moving forward on initiatives such as the LPM that are driven, in large part, by the demands of the cable industry. ${ }^{130}$ These industry stakeholder pressures conceivably extend to independent entities such as the Media Rating Council, though in theory the MRC is insulated from such pressures. Perhaps more important, then, is the fact that the MRC has no legitimate authority over audience measurement firms. The fact that firms such as Nielsen willingly move forward with new measurement services regardless of MRC reports regarding their flaws means that the existing system of industry self-regulation is not well-equipped to ensure that audience measurement systems operate under maximum accuracy and do not exhibit flaws that can have a negative impact on viewpoint and content diversity. To the extent that flawed measurement systems can undermine diversity via inaccuracies in the measurement process, policymakers should have some direct mechanism for insuring that such flawed measurement systems do not go "on-line” and impact advertiser and programmer decision-making.

\footnotetext{
${ }^{128}$ It is important to emphasize that achieving greater accuracy in audience measurement can, in some contexts, conceivably have a negative effect on viewpoint and content diversity. To the extent that the primary goal of audience measurement systems is to accurately reflect audience behavior, such instances should not be perceived as diversity policy concerns requiring some form of regulatory intervention.

${ }^{129}$ Napoli, supra note 12.

${ }^{130}$ Brooks Barnes, For Nielsen, Fixing Old Ratings System Causes New Static, WALL St. J., Sept. 16, 2004, at A8.
} 
These weaknesses in terms of the existing self-regulatory system's ability to protect viewpoint and content diversity become more pronounced when we consider some defining characteristics of the marketplace for media audiences. Specifically, it is important to recognize that there is legitimate reason for concern about whether there are sufficient market incentives to promote the effective measurement of minority audiences. Previous research has demonstrated that advertisers tend to undervalue minority audiences relative to non-minority audiences, even when controlling for other possible explanatory factors. ${ }^{131}$ These results suggest that advertisers do not feel particularly strong incentives to reach minority audiences and that, consequently, programmers for the most part do not feel particularly strong incentives to attract minority audiences. It would seem to logically follow, then, that measurement firms might not feel strong incentives to accurately measure minority audiences. The result could be lower quality audience measurement that potentially under-represents minority audiences and that magnifies pre-existing disincentives to provide minority-targeted programming - essentially creating a downward spiral of forces that undermines minority programming.

Moreover, the introductory portion of this paper illustrated the extent to which the audience measurement industry intersects with other important media policy issues, such as privacy and ownership concentration. ${ }^{132}$ These intersections provide additional rationales for policymakers to directly oversee the activities of the audience measurement industry. Certainly, it is ironic that policymakers rely so heavily upon the market definitions employed by audience measurement firms in their market analysis and policy decision-making, and yet have no oversight of how these firms define the markets that form the basis for their own competitive analyses.

If, then, as has been argued here, government oversight of the television audience measurement industry is appropriate, how should such oversight be structured? Stakeholders have called for both Federal Trade Commission and Federal Communications Commission involvement. ${ }^{133}$ As was noted

\footnotetext{
${ }^{131}$ Napoli, supra note 6. See also James G. Webster \& Patricia Phalen, The MAss AudienCE: Rediscovering the DOMINANT MODEL (1997).

${ }^{132}$ See Webster \& Phalen, supra note 130, at 5-7.

${ }^{133}$ See Press Release, News Corp., supra note 36, at 1.
} 
above, Senator Conrad Burns has directed the Federal Trade Commission to explore its possible regulatory authority over Nielsen. ${ }^{134}$ The Federal Communications Commission has not, at this point, received any similar instructions, nor has the agency become involved in the LPM issue in any way under its own initiative.

As this paper has illustrated, the primary rationales for government oversight of the audience measurement industry extend not only from its monopoly status, but also from the relationship between audience measurement and diversity of viewpoints and content. Thus, as is often the case in media regulation issues, there is an intersection between economic and non-economic policy concerns. ${ }^{135}$ This bifurcation of policy concerns has led to a model in which jurisdiction on many media policy issues is shared between the FCC and the Justice Department or Federal Trade Commission.

Audience measurement may very well be a natural monopoly. The introduction of multiple “currencies” into the process of buying and selling audiences introduces confusion, controversy, uncertainty into the audience marketplace. Moreover, it introduces substantial additional expense. Consequently, in most media sectors stakeholders have tended to support one primary purveyor of audience data and have, in fact, expressed a preference for such a model. ${ }^{136}$ For these reasons, trying to introduce and maintain greater competition in television audience measurement does not seem like an appropriate or viable strategy for addressing any of the policy concerns that arise in relation to the audience measurement industry. Rather, policymakers would be better off accepting the monopoly nature of the audience measurement industry and overseeing it accordingly. However, it is important to recognize that in a scenario in which the audience measurement business was competitive, but in which the providers, for whatever reason, appeared to inadequately measure minority audiences, legitimate policy considerations (i.e., diversity considerations) would still remain.

\footnotetext{
${ }^{134}$ See Letter to Deborah Platt Majoras, Chairman, Federal Trade Commission, supra note 84.

135 See generally Robert Entman \& Steven Wildman, Reconciling Economic and Non-Economic Perspectives in Media Policy: Transcending the "Marketplace of Ideas," 42 JOURNAL OF COMMUNICATION 7 (1992).

${ }^{136}$ See Napoli, supra note 12.
} 
This latter point reinforces the fact that, in the case of audience measurement, we again see (as we often do with media policy issues) a scenario for possible intersection and conflict between economic concerns and public interest concerns ${ }^{137}$ - a fact that needs to be taken into consideration when developing a regulatory response. Certainly, the diversity concerns inherent in the process of audience measurement extend beyond the purview of the Federal Trade Commission's expertise, corresponding instead with one of the explicit and well-established policy objectives of the Federal Communications Commission. For this reason, it is important that the FCC play a central role in any oversight of the audience measurement industry. It is this conclusion that makes the FCC's complete silence on - and apparent inattention to -- the local people meter issue a bit troubling.

Congress and the FCC should consider incorporating the services that measure television and radio audiences into the Commission's regulatory authority, with a particular emphasis on monitoring and perhaps even certifying - the methodologies employed to insure that they do not contain biases that undermine the Commission’s source and content diversity objectives. Or, at the minimum, the Commission should consider a rulemaking that prohibits measurement firms from launching new audience measurement systems prior to their receiving certification from the Media Rating Council. The fact that Nielsen Media Research has repeatedly demonstrated a willingness to launch new measurement services prior to their passing MRC scrutiny provides compelling evidence that the existing selfregulatory system is essentially toothless and needs to be either strengthened or replaced by government oversight - oversight that is attentive to the diversity implications of the process of audience measurement.

Future research should explore the wide range of legal and policy questions raised by the local people meter controversy. Is, as the Los Angeles Superior Court concluded, audience behavior data properly categorized as non-commercial speech and therefore deserving of full First Amendment protection? Are there any issues of statutory authority that might impact either the Federal Trade Commission's or the Federal Communications Commission's ability to more directly regulate the

\footnotetext{
${ }^{137}$ See Entman \& Wildman, supra note 135.
} 
audience measurement industry? Should the television audience measurement industry be considered a natural monopoly? The local people meter issue has helped to raise these questions, though these questions and their answers have implications that extend well beyond this particular audience measurement controversy, touching also on the much broader issue of the place of audience measurement in media policy. 